\title{
The Stereochemistry of Fukiic Acid and lts Correlation with Piscidic Acid
}

\author{
Teruhiko Yoshihara, Akitami Ichihara, Hanako Nuibe, Sadao SaKamura, \\ Mieko Suglta, * Shoji Imamoto* and Siro SENOH** \\ Department of Agricultural Chemistry, Faculty of Agriculture, \\ Hokkaido University, Sapporo \\ * The Institute of Food Chemistry, Osaka \\ **Central Research Institute, Suntory Ltd., Osaka
}

Received August 3, 1973

\begin{abstract}
The stereochemistry of fukiic acid (I) was elucidated. The relative configuration was determined to be erythro by IR spectrum and the evidence of acetonide formation. The absolute configuration of fukiic acid was assigned as $\mathrm{S}$-configuration at $\mathrm{C}-2$ and $\mathrm{R}$-configuration at $\mathrm{C}-3$, by Horeau's method and the identification of ozonolysis product to be hibiscus acid (10 a).
\end{abstract}

In previous papers, ${ }^{1,2\}}$ we have reported the isolation and structural determination of fukiic acid (1) which was obtained from Petasites japonicus. In preliminary communication $^{3 \prime}$ we have demonstrated that fukiic acid has the same stereochemical relationship

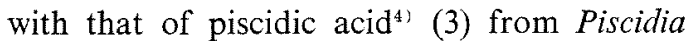
erythrina. Erythro configuration for fukiic acid (1) was further confirmed by the synthesis of a fukiic acid derivative. ${ }^{5)}$ We describe in this report the details of the stereochemical studies of fukiic acid (1).

Since fukiic acid (1) contains two asymmetric centers in its molecule, four stereoisomers consisting of two threo and erythro compounds are possible. In order to decide the relative configuration at $C_{2}$ and $C_{3}$ in fukiic acid, it is necessary to convert fukiic acid to cyclic lactone in which the $\mathrm{C}_{2}-\mathrm{C}_{3}$ bond is rigidly fixed from free rotation. Therefore $\mathrm{O}, \mathrm{O}^{\prime}$ dimethylfukiic acid dimethyl ester (2) was treated with sodium borohydride to yield a lactone. Since the lactone showed a peak at $1782 \mathrm{~cm}^{-1}$ in the IR spectrum and signals at $\delta 4.00 \sim 4.32$ due to $-\mathrm{O}-\mathrm{CH}_{2}-$ and $-\stackrel{\mathrm{I}}{\mathrm{C}} \mathrm{H}$ as multiplets in the PMR spectrum, clearly lactone $6 \mathrm{a}$ or $6 \mathrm{~b}$ was produced. For deciding correct structure the product was acetylated with acetic anhydride in pyridine to yield a diacetate $\mathrm{C}_{17} \mathrm{H}_{20} \mathrm{O}_{8}, \quad \mathrm{mp} 112 \sim 113^{\circ} \mathrm{C}$. Since in the PMR spectrum the diacetate exhibited a signal at $\delta 5.48$ assignable to the $-\mathrm{CH}$ which constituted $\mathrm{X}$ part of $\mathrm{ABX}$ system in PMR spectrum, the lactone should have the structure
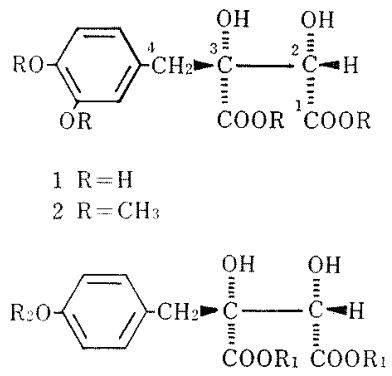

$$
\begin{aligned}
& 3 \mathrm{R}_{1}, \mathrm{R}_{2}=\mathrm{H} \\
& 4 \mathrm{R}_{1}=\mathrm{CH}_{3}, \mathrm{R}_{2}=\mathrm{H} \\
& 5 \mathrm{R}_{1}, \mathrm{R}_{2}=\mathrm{CH}_{3}
\end{aligned}
$$

FIG. 1.

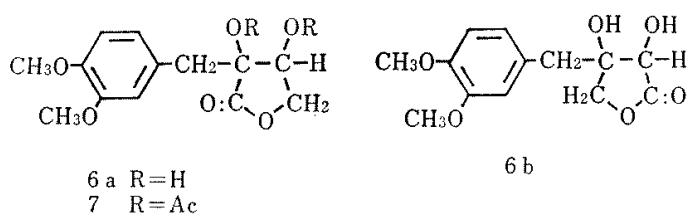

FIG. 2. 


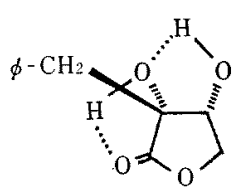

$8 a$

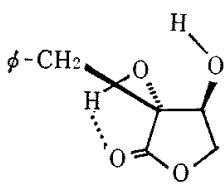

$8 c$

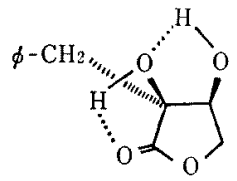

$8 b$

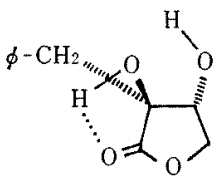

$8 \mathrm{~d}$

FIG. 3.

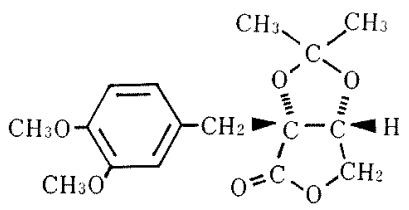

9

FIG. 4.

depicted as 7. The infrared spectrum of the lactone (6a) in dilute carbon tetrachloride $\left(3.1 \times 10^{-4}\right.$ mole $)$ showed an intramolecular hydrogen bonded absorption band at 3575 $\mathrm{cm}^{-1}$ which afforded the evidence for hydrogen bonded structure $8 \mathrm{a}$ or $8 \mathrm{~b}$. If the lactone has a structure $8 \mathrm{c}$ or $8 \mathrm{~d}$, and absorption band due to a free hydroxyl group in higher frequency will be appeared. The result means that the lactone has a cis diol system. Further evidence for cis configuration was obtained by the formation of its acetonide. Thus the lactone was treated with acetone in the presence of $p$-toluenesulfonic acid to give an acetonide whose spectroscopic data and elemental analysis are precisely compatible with the structure 9 .

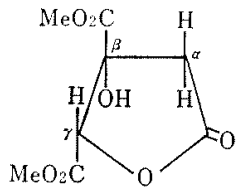

$10 \mathrm{a}$

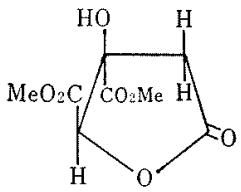

$10 \mathrm{~b}$

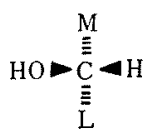

A

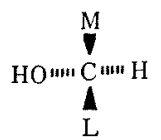

B

FIG. 5.

The absolute configuration at $\mathrm{C}-2$ in fukiic acid was established by the method developed by Horeau ${ }^{6,7)}$ for determining the configuration of asymmertric center containing a secondary hydroxyl group. Thus excess racemic $\alpha$-phenylbutyric anhydride $\left(3.47 \times 10^{-4}\right.$ mole) was treated with the lactone $(6 \mathrm{a}, 1.87 \times$ $10^{-4}$ mole) in pyridine. After hydrolysis, resultant product which exhibits corresponding singals to $\alpha$-phenyl butyrate of the lactone in the PMR spectrum was obtained from neutral fraction. On the other hand, from acidic fraction, an acid which was identical with authentic $\alpha$-phenyl butyric acid in the IR spectrum was obtained, and exhibited dextrorotatory, $(+)$, then the absolute configuration at $\mathrm{C}-2$ of the lactone is represented by formula $\mathrm{A}$ in which $\mathrm{L}$ refers to the sterically $\mathrm{O}$

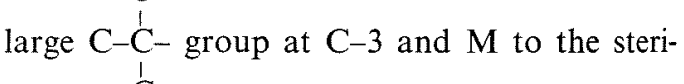
C

cally small $-\mathrm{CH}_{2}-$ group at $\mathrm{C}-1$. Based on the Horeau's procedure, $\mathrm{C}-2$ asymmetric center of fukiic acid (1) must have the absolute configuration S. When acyclic compound (2) was used for Horeau's method, recovered $\alpha$ phenylbutyric acid exhibited slight levorotatory, $-1.1^{\circ}$ This result indicates that the confguration at $\mathrm{C}_{2}$ is represented by formula $\mathrm{B}$ assuming the order of substituent group in bulkiness as $-\mathrm{COOCH}_{3}>-\stackrel{\mathrm{C}}{\mathrm{COOCH}}-\mathrm{OH}$ which

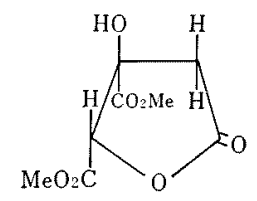

$10 \mathrm{c}$

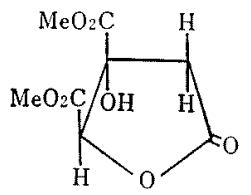

$10 \mathrm{~d}$

FIG. 6 
The Stereochemistry of Fukiic Acid and Its Correlation with Piscidic Acid

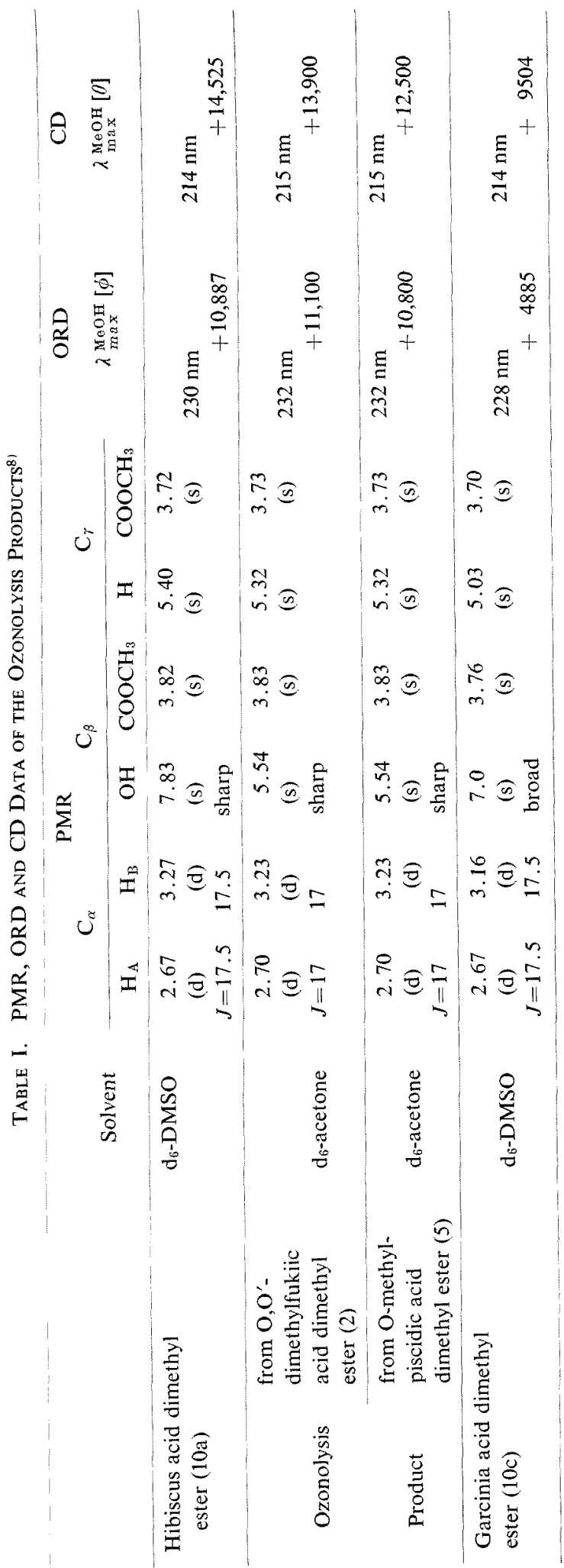


might be resulted from solvation of methyl ester group. This provides the same results as that of the cyclic compound $6 \mathrm{a}$ described above.

Further support for the absolute configuration was obtained by ozonolysis ${ }^{8)}$ of $\mathrm{O}, \mathrm{O}^{\prime}-$ dimethylfukiic acid dimethyl ester (2) to one of the known compounds, hibiscus acid dimethyl ester (10a), its enantiomer (10b), garcinia acid dimethyl ester (10c) and its enantiomer (10a) whose stereochemistries had been unequivocally established. ${ }^{9)} \quad$ Thus ozonolysis of the ester (2) afforded a syrup whose PMR, ORD and $C D$ data are quite compatible with those of hibiscus acid dimethyl ester (10a) (Table I). Since absolute configuration of $\mathrm{C}_{\beta}$ and $\mathrm{C}_{Y}$ in hibiscus acid are known as $\mathrm{R}$ and $\mathrm{S}$ respectively, it is concluded that fukiic acid has S-configuration at $\mathrm{C}-2$ and R-configuration at C-3. This is the same result with that of Horeau's procedure. Based on all the evidences presented above, we propose stereostructure I for fukiic acid. And as hibiscus acid dimethyl ester (10a) was obtained from O-methylpiscidic acid dimethyl ester (5) in a similar manner, the stereochemistry for piscidic acid should be depicted as 3 .

Finally, in order to confirm the identity of the stereochemistry of fukiic acid and that of piscidic acid, piscidic acid dimethyl ester (4) was ortho-hydroxylated through photo-oxygenation $^{10)}$ and methylated. The resultant product was entirely identical with $\mathrm{O}, \mathrm{O}^{\prime}$ dimethylfukiic acid dimethyl ester (2) in PMR, IR, mass spectrum, TLC and optical rotation. Therefore, according to the previous result, it is concluded that both compounds have the same absolute configuration.

\section{EXPERIMENTAL}

The $\mathrm{mp}$ were determined on a Yanaco digital micromelting point apparatus model MP-3D. PMR spectra were taken with a Hitachi $\mathrm{H}-60(60 \mathrm{MHz})$ and Japan Electron Optics, JNM PS-100 (100 MHz) instruments using TMS as internal reference. The mass spectra were recorded on Hitachi RMS-4 mass spectrometer and the IR spectra on a Hitachi EPI-S2 infrared spectrometer. $\mathrm{CD}$ and $\mathrm{ORD}$ were measured with JASCO ORD-UV-5. Optical rotations were determined with Hitachi POB polarimeter. orthoHydroxylation was carried out with Ushio ULI5BQ.

Preparation of 2,3,4-trihydroxy-2-(3',4'-dimethoxy. benzyl)-butyric acid $\gamma$-lactone $(6 a)$

To a solution of $480 \mathrm{mg}(1.46 \mathrm{~mm})$ of the dimethyl ester (2) in $25 \mathrm{ml}$ of ethanol, $83 \mathrm{mg}(2.19 \mathrm{~mm})$ of sodium borohydride was added and stirred for $2 \mathrm{hr}$ at room temperature. After acidification with $1 \mathrm{~N}$ hydrochloric acid, the reaction mixture was concentrated in vacuo and the residue was extracted several times with chloroform. The combined extracts were concentrated and the concentrate was fractionated on a silica gel column ( $5 \mathrm{~g}$ ) using chloroform as solvent. Each fraction was monitored by UV spectrum and fractions having absorption at $280 \mathrm{~nm}$ were collected and evaporated in vacuo to give $110 \mathrm{mg}$ of the lactone (6a) in $28.2 \%$ yield. IR $\nu_{\mathrm{max}}^{\mathrm{CCl}_{4}} \mathrm{~cm}^{-1}: 1782$. PMR $\delta \mathrm{T}_{6 \text {-acetone }}^{\mathrm{d}_{\text {tas }}}(60 \mathrm{MHz}): 2.95\left(2 \mathrm{H}, \mathrm{s}, \phi-\mathrm{CH}_{2-}\right), 3.76(6 \mathrm{H}$, $\left.\mathrm{s}, 2 \mathrm{CH}_{3} \mathrm{O}-\right), 4.0 \sim 4.32\left(3 \mathrm{H}, \mathrm{m},-\underset{\mathrm{C}}{\mathrm{C}} \mathrm{H}\right.$ and $\left.-\mathrm{O}-\mathrm{CH}_{2}-\right)$, $6.82(2 \mathrm{H}, \mathrm{s}, \mathrm{ArH}), 6.92(1 \mathrm{H}, \mathrm{s}, \mathrm{ArH})$. The IR spectrum of the lactone under high dilute solution $\left(3.1 \times 10^{-4}\right.$ mole) in dried carbon tetrachloride using $50 \mathrm{~mm}$ quartz cell showed single peak at $3575 \mathrm{~cm}^{-1}$ corresponding to intramolecular hydrogen bonded hydroxyl group.

\section{Acetylation of the lactone ( $6 a$ )}

A mixture of $67 \mathrm{mg}$ of the lactone $(6 \mathrm{a})$ in $1 \mathrm{ml}$ of acetic anhydride and $1 \mathrm{ml}$ of pyridine was allowed to stand for 3 days. The reaction mixture was concentrated in vacuo to give a residue which was recrystallized from chloroform-cyclohexane to yield $34.1 \mathrm{mg}$ of a crystalline diacetate (7), $\mathrm{mp} 112 \sim 113^{\circ} \mathrm{C}$. Anal. Found: $\mathrm{C}, 57.76 ; \mathrm{H}, 5.60$. Calcd. for $\mathrm{C}_{17} \mathrm{H}_{20} \mathrm{O}_{8}$ : $\mathrm{C}, 57.95 ; \mathrm{H}, 5.68 \%$. IR $\nu_{\max }^{\mathrm{KBr}} \mathrm{cm}^{-1}: 1785,1755,1240$. PMR $\delta_{\mathrm{TMS}}^{\mathrm{CDC}_{3}}(60 \mathrm{MHz}): 2.06\left(3 \mathrm{H}, \mathrm{s}, \mathrm{CH}_{3} \mathrm{CO}-\right), 2.15$ $\left(3 \mathrm{H}, \mathrm{s}, \mathrm{CH}_{3} \mathrm{CO}-\right), 3.28\left(2 \mathrm{H}, \mathrm{s}, \mathrm{Ar}-\mathrm{CH}_{2}-\right), 3.86(6 \mathrm{H}, \mathrm{s}$, $\left.2 \mathrm{CH}_{3} \mathrm{O}-\right), 3.70 \sim 4.25\left(2 \mathrm{H}, \mathrm{m}, \mathrm{O}-\mathrm{CH}_{2-}\right), 5.48(1 \mathrm{H}$, dd, $\left.-\stackrel{1}{C} \mathrm{H}, J_{\mathrm{AX}}=4.8, J_{\mathrm{BX}}=7.8 \mathrm{~Hz}\right), 6.82(3 \mathrm{H}, \mathrm{s}, \operatorname{ArH})$.

\section{The acetonide $(9)$ of the lactone $(6 a)$}

A solution of $42.7 \mathrm{mg}$ of the lactone $(6 \mathrm{a})$ and $128 \mathrm{mg}$ of $p$-toluenesulfonic acid in $1 \mathrm{ml}$ of dry acetone was allowed to stand for $60 \mathrm{hr}$ at room temperature. To the reaction mixture $25 \mathrm{ml}$ of chloroform and $25 \mathrm{ml}$ of $1 \%$ sodium bicarbonate solution was added. Organic layer was washed three times with water and dried over anhydrous sodium sulfate. The solution was evaporated in vacuo to yield a residue which was recrystallized from ethanol-petroleum ether to give $30.0 \mathrm{mg}$ of the acetonide (9), mp $135 \sim 136^{\circ} \mathrm{C}$. Anal. Found: $\mathrm{C}, 62.38 ; \mathrm{H}, 6.46$. Calcd. for $\mathrm{C}_{16} \mathrm{H}_{20} \mathrm{O}_{6}: \mathrm{C}$, $62.34, \mathrm{H}, \quad 6.49 \% . \quad$ IR $\nu \underset{\max }{\mathrm{KBr}} \mathrm{cm}^{-1} 1776,1380$. 
PMR $\delta{ }_{\mathrm{TMS}}^{\mathrm{CDCl}_{3}}(100 \mathrm{MHz}): 1.27\left(3 \mathrm{H}, \mathrm{s}, \mathrm{CH}_{3}-\mathrm{C}\right), 1.44$ $\left(3 \mathrm{H}, \mathrm{s}, \mathrm{CH}_{3}-\mathrm{C}\right), 3.05$ and $3.25(2 \mathrm{H}, \mathrm{ABq}, J=14 \mathrm{~Hz}$, $\left.\mathrm{Ar}-\mathrm{CH}_{2}-\right), 3.54\left(1 \mathrm{H}\right.$, dd, $\mathrm{A}$ part of $\mathrm{ABX}, J_{\mathrm{AB}}=12$ and $\left.J_{\mathrm{AX}}=4 \mathrm{~Hz},-\mathrm{O}-\mathrm{CH}_{2}-\right), 3.87\left(6 \mathrm{H}, \mathrm{s}, 2 \mathrm{CH}_{3} \mathrm{O}-\right), 4.20$ $\left(1 \mathrm{H}, \mathrm{d}, \mathrm{B}\right.$ part of $\left.\mathrm{ABX}, J_{\mathrm{AB}}=12 \mathrm{~Hz},-\mathrm{O}-\mathrm{CH}_{2}-\right), 4.55$ $\mathrm{OH}$

(1H, d, X part of ABX, $\left.J_{\mathrm{AX}}=4 \mathrm{~Hz},-\stackrel{\mathrm{C}}{\mathrm{H}}\right), 6.76(3 \mathrm{H}, \mathrm{s}$, $\mathrm{ArH})$. MS $m / e: 308\left(\mathrm{M}^{+}\right), 293\left(\mathrm{M}^{+}-{ }^{\prime} \mathrm{H}_{3}\right), 157\left(\mathrm{M}^{+}\right.$ $\left.\mathrm{CH}_{2} \mathrm{Ar}\right), 151$ (MeO- $\mathrm{CH}_{2}$, base peak), 59 $\left(\begin{array}{l}\mathrm{CH}_{3} \\ \mathrm{CH}_{3}\end{array}, \mathrm{C}=\dot{\mathrm{O}} \mathrm{H}\right), 43\left(\mathrm{CH}_{3}-\mathrm{C} \equiv \stackrel{+}{\mathrm{O}}\right)$.

\section{Determination of absolute configuration}

a) By Horeau's method. A solution of $50.0 \mathrm{mg}$ $(0.187 \mathrm{~mm})$ of the lactone (6a) and $115.8 \mathrm{mg}(0.374 \mathrm{~mm})$ of freshly prepared $\alpha$-phenylbutyric anhydride in $4 \mathrm{ml}$ of pyridine was allowed to stand for $24 \mathrm{hr}$ at room temperature under dark. To the reaction mixture, $20 \mathrm{ml}$ of water was added and stand for additional $2.5 \mathrm{hr}$. After addition of $100 \mathrm{ml}$ of water the mixture was extracted three times with $25 \mathrm{ml}$ of chloroform and the combined extracts were washed with $100 \mathrm{ml}$ of water and three times with $50 \mathrm{ml}$ of $5 \%$ sodium bicarbonate and finally with $75 \mathrm{ml}$ of water. The extracts were dried over anhydrous sodium sulfate and evaporated in vacuo to give $64.0 \mathrm{mg}$ of esterified compound as neutral fraction. PMR $\delta{ }_{\mathrm{TMS}}^{\mathrm{d}_{6} \text {-acetone }}(60 \mathrm{MHz})$ : signals due to lactone; $3.0\left(2 \mathrm{H}, \mathrm{s}, \mathrm{Ar}-\mathrm{CH}_{2}-\right), 3.76(6 \mathrm{H}$, $\left.\mathrm{s}, 2 \mathrm{CH}_{3} \mathrm{O}-\right), 3.90 \sim 4.4\left(2 \mathrm{H}, \mathrm{m}, \mathrm{O}-\mathrm{CH}_{2}-\right), 5.1 \sim 5.4$ $(1 \mathrm{H}, \mathrm{m},-\mathrm{C} H), 6.80(2 \mathrm{H}, \mathrm{s}, \mathrm{ArH}), 6.87(1 \mathrm{H}, \mathrm{s}, \mathrm{ArH})$. Signals due to $\alpha$-phenylbutyric acid; $0.84(3 \mathrm{H}, \mathrm{t}, J=$ $7.2 \mathrm{~Hz}, \mathrm{CH}_{3}-$ ), $1.7 \sim 2.6$ (overlapped with signals of acetone, $\left.-\mathrm{CH}_{2}-\right), 3.60(1 \mathrm{H}, \mathrm{t}, J=7.8 \mathrm{~Hz},-\underset{\mathrm{C}}{\mathrm{C}} \mathrm{H}), 7.3$ $(5 \mathrm{H}, \mathrm{s}, \mathrm{ArH})$. The alkaline layer was extracted with $150 \mathrm{ml}$ of chloroform and acidified with $2 \mathrm{~N}$-hydrochloric acid. The acidic solution was extracted three times with $200 \mathrm{ml}$ of ether. The combined extracts were dried over anhydrous sodium sulfate and concentrated under reduced pressure to give $79.4 \mathrm{mg}$ of optically active $\alpha$-phenylbutyric acid. The IR and PMR spectra were identical with those of authentic sample. $[\alpha]_{\mathrm{D}}^{18}+7.97^{\circ}(c=3.97$, benzene $)$ optical yield $25 \%$.

b) By ozonolysis of the dimethyl ester (2) to hibiscus acid dimethyl ester $(10 \mathrm{a})$. To a solution of $22 \mathrm{mg}$ of the ester (2) in $20 \mathrm{ml}$ of distilled water, ozone was bubbled for $3 \mathrm{hr}$ at $0^{\circ} \mathrm{C}$. The reaction mixture was heated with $2 \mathrm{ml}$ of $30 \%$ aqueous hydrogen peroxide solution on water bath for $30 \mathrm{~min}$ to decompose the ozonide. After concentration of the mixture under reduced pressure, $30 \mathrm{ml}$ of methanol saturated with dry hydrogen chloride was added and the solution was refiuxed gently for $3 \mathrm{hr}$. The reaction mixture was evaporated to dryness and the residue was separated on a preparative TLC using silica gel. Ether extraction from the fraction at about $R f 0.4$ on the TLC gave $3.1 \mathrm{mg}$ of hibiscus acid dimethyl ester (10a). PMR, ORD and $\mathrm{CD}$ data of the ozonolysis product are summerized on Table $\mathrm{I}$.

Ozonolysis of O-methyl piscidic acid dimethyl ester (5)

To a solution of $92.9 \mathrm{mg}$ of the ester (5) in $25 \mathrm{ml}$ of distilled water, ozone was bubbled for $10 \mathrm{hr}$ at $0^{\circ} \mathrm{C}$. The reaction mixture was heated with $3 \mathrm{ml}$ of $30 \%$ aqueous hydrogen peroxide solution for $30 \mathrm{~min}$ at $100^{\circ} \mathrm{C}$. After concentration of the mixture, the same treatment described above gave $15 \mathrm{mg}$ of oil whose PMR, ORD and CD data are summerized on Table I.

ortho-Hydroxylation of piscidic acid dimethyl ester (4)

After nitrogen was introduced for $30 \mathrm{~min}$ into the aqueous solution $(17 \mathrm{ml})$ of piscidic acid dimethyl ester (4) (250 mg) obtained from Narcissus poeticus ${ }^{11}$ ) and $30 \%$ aqueous hydrogen peroxide solution $(2 \mathrm{ml})$, the mixture was irradiated with low-pressure mercury lamp $(2537 \AA)$ at room temperature for $2 \mathrm{hr}$. After concentrating to about $1 \mathrm{ml}$, the reaction mixture was separated by preparative paper chromatography using $n$-butanol-acetic acid-water $(4: 1: 5, \mathrm{v} / \mathrm{v})$. The main band ( $R f$ value at about 0.8 ) which is colored with phenol reagent ${ }^{12}$ was scissored, extracted with water $(300 \mathrm{ml})$ and the extracts were evaporated to dryness. A solution of the phenol compound in a small amount of acetone was treated three times with about $0.3 \mathrm{M}$ diazomethane $(20 \mathrm{ml})$. The methylated mixture was passed over a silica gel column (10 g) eluting with $70 \%$ chloroform in cyclohexane. Monitoring with UV spectrophotometer fractions which have absorption band at $280 \mathrm{~nm}$, the major peak $(175 \sim 250 \mathrm{ml})$ were collected and evaporated in vacuo. The residue was crystallized from chloroform-cyclohexane. Yield $21 \mathrm{mg}, \mathrm{mp} 116.0^{\circ} \mathrm{C}$ (lit., ${ }^{2)} 117 \sim 118^{\circ} \mathrm{C}$ ). Anal. Calcd. for $\mathrm{C}_{15} \mathrm{H}_{20} \mathrm{O}_{8}: \mathrm{C}, 54.87 ; \mathrm{H}, 6.14$. Found: $\mathrm{C}, 54.90$; $\mathrm{H}, 6.13 \% .[\alpha]_{\mathrm{D}}^{24.5}+48.2(c=0.975, \mathrm{EtOH})\left(\mathrm{O}, \mathrm{O}^{\prime}-\right.$ dimethylfukiic acid dimethyl ester; $[\alpha]_{\mathrm{D}}^{12}+50.2^{\circ}(c=$ 1, EtOH)). MS m/e: $328\left(\mathrm{M}^{+}\right), 151$ (base peak,

$\left.\mathrm{MeO}-\mathrm{MeO}-\mathrm{CH}_{2}\right)$. PMR $\delta_{\max }^{\mathrm{CDCl}_{3}}(100 \mathrm{MHz}): \quad 3.04$ and $3.32\left(2 \mathrm{H}, \mathrm{ABq}, J=13 \mathrm{~Hz}, \mathrm{Ar}-\mathrm{CH}_{2}-\right), 2.6 \sim 3.4$ $(2 \mathrm{H}, \mathrm{br},-\mathrm{OH}), 3.76\left(3 \mathrm{H}, \mathrm{s},-\mathrm{OCH}_{3}\right), 3.86\left(3 \mathrm{H}, \mathrm{s},-\mathrm{OCH}_{3}\right)$, $4.55\left(1 \mathrm{H}, \mathrm{s},-\frac{1}{\mathrm{C}} \mathrm{H}\right), 6.6 \sim 6.9(3 \mathrm{H}, \mathrm{m}, \mathrm{ArH})$. TLC: benzene-acetone $(8: 2, \mathrm{v} / \mathrm{v}), \operatorname{Rf} 0.17$; ethyl acetatecyclohexane $(1: 1, \mathrm{v} / \mathrm{v}), \operatorname{Rf} 0.15$.

\section{REFERENCES}

1) S. Sakamura, T. Yoshihara and K. Toyoda, Agr. Biol. Chem., 33, 1795 (1969).

2) Idem, ibid., 37, 1915, (1973). 
3) T. Yoshihara, A. Ichihara, S. Sakamura, M. Sugita, S. Imamoto and S. Senoh, Tetrahedron Letters, 1971, 3809.

4) W. Bridge, F. Coleman and A. Robertson, $J$. Chem. Soc., 1948, 257.

5) T. Yoshihara, A. Ichihara and S. Sakamura, Agr. Biol. Chem., 35, 1822 (1971).

6) A. Horeau, Tetrahedron Letters, 1961, 506.

7) Idem, ibid., 1962, 965.

8) S. Senoh, Y. Maeno, S. Imamoto, A. Komamine, S. Hattori, K. Yamashita and M. Matsui, Bull.
Chem. Soc. Japan, 40, 379 (1967).

9) P. M. Boll, E. Sørensen and E. Balieu, $A c$ Chemica Scand., 23, 286 (1969).

10) K. Omura and T. Matsuura, Tetrahedron, 2 3475 (1968).

11) R. R. Smeby, V. Zbinovsky, R. H. Burris ar F. M. Strong, J. Amer. Chem. Soc., 76, 61' (1954).

12) O. Folin and V. Ciocalteu, J. Biol. Chem., 7 627 (1927). 